This is an Author's Accepted Manuscript of an article published in the Journal of Postcolonial Writing, Vol. 49, No. 2 (2013) pp. 174-186 [copyright Taylor \& Francis], available online at: http://www.tandfonline.com/doi/full/10.1080/17449855.2013.776378\#.UahtGpUTHHg 


\section{Philosophy of the Imagination: Time, Immanence and the Events that Wound Us in Wilson Harris's Jonestown}

LORNA BURNS, UNIVERSITY OF ST ANDREWS

1mb21@st-andrews.ac.uk

In his fictional recreation of the People's Temple massacre, Jonestown, Harris presents us with a protagonist who counter-actualizes the trauma that wounds him, living creatively out of the event and constructing an alternative present-future. Drawing on Deleuzian philosophy, this essay argues for a re-conceptualization of Jonestown in terms that evoke not only Deleuze's philosophy of time and immanence but also his distinction, via Nietzsche, between active and reactive forces. By means of a character (Francisco Bone) who embraces the power of transformation, creation and difference-in-itself, Harris demonstrates the value of active forces that do not depend on external recognition or dialectical negation in order to be for a postcolonial philosophy of the imagination.

Keywords: Jonestown; Wilson Harris; Gilles Deleuze; the event; time; immanence.

From Palace of the Peacock (1960) to The Ghost of Memory (2006), Wilson Harris has displayed a commitment to a vitalist sense of immanent creativity within the context of diverse histories of conquest and exploitation. Resonant with the work of fellow Caribbean author-philosopher, Édouard Glissant, Harris's sense of a diverse, creolizing and, importantly, always-incomplete and non-absolute totality or wholeness reflects a concurrent shift in contemporary European philosophy from transcendence to immanence as the basis of ontology. ${ }^{1}$ Indeed, the interest in a non-linear concept of time, the transformative capacity of the past, difference and a radical sense of the new characterize the postcolonial projects of both Glissant and Harris as much as the 
philosophy of one of the key figures in the "post-continental" turn to immanence, Gilles Deleuze (cf. Burns). This essay is concerned with Harris's own philosophy of immanence and time developed through his fictional and theoretical writings, in particular, the novel Jonestown (1996). In his imaginative recreation of the Jonestown tragedy in which over 900 members of the People's Temple died on the 18 November 1978, Harris exposes the recreative potential of the past: the challenge to create a new future while bearing forth the scars of the wounding event. And it is precisely the regenerative capacity of the event that marks Harris as a profoundly postcolonial writer and thinker. As Edward Said argued in Culture and Imperialism:

Many of the most interesting post-colonial writers bear their past within them - as scars of humiliating wounds, as instigation for different practices, as potentially revised visions of the past tending towards a new future, as urgently reinterpretable and redeployable experiences, in which the formerly silent native speaks and acts on territory taken back from the empire. (34-5; emphasis added)

The question of how one responds to or lives with such "humiliating wounds" lies at the heart of Jonestown and, in turn, remains a distinctive feature of postcolonial philosophy, as distinguished from the reactive forces of counter-colonial opposition. For Harris, as for Said and, indeed, Deleuze, the potential of "a new future" is born of a different relation to the past traumas that wound us.

While Harris's interest in cross-culturalism and fractured selves has appealed to his critics, the vital question of his sense of "immanence" has received scant attention. Both Mary-Lou Emery and Hena Maes-Jelinek, for example, refer to 
transcendence and immanence in Harris, but consider only briefly the contentious question of the relationship between the two. As Maes-Jelinek argues, Harris's sense of the unconscious, abyss, and archetypes refer to:

[an] inner transcendence, a "transcendence within immanence" [Levinas], as opposed to a transcendence external to man and beyond his normal experience. But again, this descent would itself be in search of an infinite absolute were it not counterpointed by the emergence of the plural otherness [ ... ] thereby transcending the limits of the individual self. (6)

To this, Emery adds that in Harris one finds a "dialectic of transcendence and immanence whereby the transcendent is known through the immanent" and, as such, "any hierarchy of being that would elevate the transcendent" is undone (69). It is clear from both accounts that Harris resists any a priori and absolute notion of the transcendent in favour of an immanent diversity-in-unity. However, Maes-Jelinek's approach to transcendence is predicated on the role of the individual or inner self, which is always already rendered a fallacy by Harris's sense of multiplicity or "plural otherness". Understanding precisely how Harris envisions the relation between immanence and transcendence is key to understanding the philosophical strength of vision that his work articulates. As James Williams argues with respect to the philosopher Alfred Whitehead, Whitehead's work details "the dance of transcendence and immanence" (95) insofar as he offers us a relational rather than absolute model of transcendence and immanence conceived of as a "becoming of different kinds and with different, but complementary, processes" (97). In other words, Whitehead's philosophy seeks to address the crucial problem of the status of actual, seemingly 
coherent identities or states of affairs within immanence. While the departure from a fixed, static and absolute concept of being (transcendence) is necessary, immanence understood as pure difference, "an entirely fluid world" (Whitehead qtd in Williams 97), can become equally problematic if it offers no ground for conceptualizing real change or newness. By characterizing Harris's work as caught between immanence and transcendence, promoting a sense of immanence that is always, impossibly, articulated through the individual or inner self, Maes-Jelinek touches upon but fails to fully recognize the complexity of the contentious philosophical demand to explain the production of the actual or finite within infinite immanence. If transcendence is really only evoked by Harris to designate, recalling Whitehead, a process by which the seemingly-coherent individual is "transcended" into an immanent totality, then we are still left with the question of how such non-absolute "fixities" (the individual, the self) emerge in the first place. We will need to take Maes-Jelinek's argument much further to better understand Harris's philosophical vision of immanence and transcendence.

More problematic, I believe, is Emery's reference to the dialectical movement of Harris's fiction. Later in her essay, Emery conflates immanence with the material world, and posits the transcendent as the revelation of an inner insight that is always already present (Emery 74). As such, she adopts a distinctly Hegelian approach to Harris's work, viewing dialectical process as the unfolding of a pre-given unity or final synthesis. This, Simone Bignall argues in her recent analysis of the problem of Hegelian thought in postcolonial theory, leaves us in a situation in which "reality is not 'created' but 'realised' [ ... ] in the sense that everything that comes to be always already exists, or is pre-given, and is simply 'made real'" (34). Harris's sense of the necessity to create the "genuinely new" (Jonestown 6), therefore, is undermined by this dialectical "unfolding”. As Deleuze argues in Difference and Repetition, "genuine 
creation" cannot "result from any limitation of a pre-existing possibility" (264). Accordingly, Harris's own sense of the urgent need to create new futures in the face of totalitarian and violent pasts is undermined by the imposition of a dialectical framework.

In my view, both Emery and Maes-Jelinek are right to insist on a parallelism of the material, actual world of concrete individuations and actual selves, and a "transcendent" realm of ungraspable otherness in Harris. However, to present this as two sides of a dialectical transformation is to misunderstand the radical sense of newness in Harris's work. Hegel may indeed offer us an immanent process (the dialectic) that accounts for evolution and change, but it remains a process directed towards a pre-given final synthesis. As such, Deleuze would argue, Hegel falls into the trap of Platonism which offered a transcendence "situated within the field of immanence itself" (Deleuze, Essays 137; emphasis original): a pre-determined ideal against which all that comes to be may be measured and judged. The absolute and the a priori are antithetical to Harris's sense of creativity, immanence and diversity: the absolute "irons out, smoothes out, erases all differences in favour of a universal formula. Everything would be flattened out presumably in the simplicity of a triumphant code" (Harris, Essays 64). This erasure of difference, Bignall argues, points precisely to the problem with Hegelian dialectics when applied to postcolonial thought: oriented towards final synthesis, dialectical process is "aimed at the management of difference" (Bignall 18) and, thus, when applied in postcolonial thinking, "proposes solutions to colonialism that are unable to break free from a fundamentally imperial outlook and attitude" (20).

By contrast, with Deleuze one finds a philosophy of becoming and change committed to the proliferation (or eternal return) of difference. The philosophy of 
immanence developed by Deleuze eschews Platonic and Hegelian transcendencewithin-immanence and instead offers a transcendental empiricism. Not to be misunderstood as a return to transcendence (Colebrook 71), transcendental empiricism explores the processes by which actual states of affairs come to be what they are. Recalling Whitehead's caution against a formless, chaotic immanence, Deleuze characterizes transcendental empiricism as a philosophy rooted in the material world and concerned with the ways in which specific states of affairs take shape within immanence. Importantly, however, it points towards a model of being that escapes the trappings of final synthesis. As Deleuze argues in The Logic of Sense, the immanent cause of actual identities or state of affairs is the virtual (118): a plane of absolute difference which acts as the transcendental condition of all actual things. By positing an actual-virtual dualism at the heart of philosophy, Deleuze should not be misread as returning to the "Cartesian dualism" that Harris dismisses (Harris Essays 185). Rather, Deleuze follows that great opponent of Descartes, Baruch Spinoza, and posits the actual and the virtual as the two sides of a single, immanent whole. As a plane of pure difference, the actualization of the virtual designates the production of the new; an always-renewed potential or eternal return, given the constitution of the virtual as difference.

Individuation within immanence occurs in two moments: first, a plane of consistency is "differentiated" within the virtual; secondly, an actual form is "differenciated" as the becoming-actual of the virtual content. What I want to emphasize here is the characterization of different/ciation as an immanent process by which the virtual, the transcendental (but not transcendent) condition of the actual, both fuels the production of newness and eternally preserves difference. The aim of postcolonial thought freed from the dialectical logic of imperialism therefore is 
twofold: “the disruption and 'counter-actualisation' of the problematic post-colonial present that remains tied to the virtual conditions of the emergence of colonisation, and the subsequent reconstruction of an alternative postcolonial present" (Bignall 114). In turn, Said's claim that from the "scars of humiliating wounds" of the colonial past "a new future" can emerge (34-35), may be reconceived as a counteractualization of the scars of history: a return to the injustices of the imperial past in order to reconstruct an alternative, genuinely postcolonial present-future.

While Harris does at times employ the term "dialectical", in my view, his work is best understood in light of a philosophical concept of immanence and Deleuzian/Spinozist dualism (cf. Burns). As Emery and Maes-Jelinek recognize, consistent throughout his oeuvre is a rejection of absolutes, final or transcendent causes and a priori concepts. For Harris, a strictly dialectical method by which the contrasting of opposites resolves itself in the realization of an always present totality points towards "our misunderstanding of evolution. Evolution in its innermost unfathomable coherence within parallel universes is intangible. It serves hidden texts that we can never absolutely translate" (Jonestown 139). The intangible, vitalisitic force of evolution resonates more closely with Deleuze's sense of different/ciation as the always-renewed production of difference than with dialectical progression towards a pre-determined absolute. And in the face of oppositional and "adversarial cultures" (Harris, Essays 58) which make us "the prisoner of inflexible sovereignty [ ... ] sovereign ego" (59), he proposes a "cross-cultural body of civilization" (58): "If one polarizes the world dreadfully, the oppressor and the oppressed, then one is no longer in a position to understand who the oppressor is, how he relates to one, who the oppressed are, how the oppressed relate to one" (85). The immanent unity of the 
whole (actual-virtual) demands an understanding of ourselves as partial, sharing in elements of extremity, such as good and evil, self and other.

In Jonestown, the connection between imperialism and "the management of difference" comes to the fore in the novel's account of the utopian ambitions of Jonah Jones, Harris's fictional recreation of Jim Jones, leader of the People's Temple and instigator of the mass suicide that took place in Guyana in 1978. Jones first appears to the reader outside the Church of Eternity in a scene of death and violence, wearing “an air of triumph like a general's on the field of battle" (Harris, Jonestown 13). Jones, Francisco Bone (the novel's narrator) and Deacon each share the burden of responsibility with respect to the tragedy insofar as they are presented as the three founding figures of the cult: Jones the authoritarian figurehead, Bone "his left-hand man" and Deacon "his right-hand angel" (16). A number of references in the novel draw a parallel between Deacon and Lucifer, the fallen angel: "No one fathoms Deacon's ancestry. He fell from the stars as an infant child. War in heaven, rebellions in heaven, it is said" (47). However, this is a Miltonian Lucifer, and Harris contrasts his act of rebellion against "the tyranny of heaven" (Milton 21) with Jones's "perverse longing for glory" (Harris, Jonestown 52). While both characters share a common “[a]nger at injustices everywhere", Harris draws attention to the danger that such sentiments "could turn nasty and become an involuntary ape of imperial hubris" (50):

Jones - in the Mask of the Whale into which he descended at times - raged at the prejudices, the biases, the hypocrisy, that were visible everywhere. His anger therefore appealed to us. But it left me with a bitter taste in my mouth. I did not like the way he savoured anger as if it were the sweetest dish in the 
restaurants of San Francisco. Anger became the seed of his charismatic pursuit of eternity, eternity's closure of time. (49-50; emphasis original)

The anger that Jones harbours fuels his will-to-dominate; by contrast, Bone and Deacon evoke the transformative capacity of the Carib bone-flute (alluded to by the protagonist's name and his discussion of the Carib's "ritual morsel" [16]) and embrace the power of creation, or will-to-power.

Harris notes the philosophical resonances of the bone-flute in his essays, where the instrument is refigured as a bridge between self and other. While the Carib's ritual cannibalism is a sign of a will-to-dominate, Harris rereads the boneflute which was carved from the body of the vanquished enemy as the transferral of spirit; transcending the binary division of life and death: "The bone-flute was a confessional organ involved in, yet subtly repudiating, the evil bias of conquest that afflicted humanity. It sought to invoke an apparition of re-birth clothed in colour and music. [... A] re-birth into unknown futures to be ceaselessly created" (Harris, Essays 106). By incorporating the spirit and knowledge of the enemy, the bone-flute suggests the way in which appearances taken "as absolute or total" (106) may be revealed as partial. More crucially, however, it signals a process of incorporation and transformation: the adversarial impulse to dominate is overcome and the relation between self and other, life and death, becomes the ground of re-creative transformation and gateway to "unknown futures". And it is in this capacity that Bone evokes Carib ritual in Jonestown. As Jones, Deacon and Bone sit together eating dinner the night before the tragedy, Bone discusses the rituals of the Caribs: 
"The Caribs ate a ritual morsel", I said, "on the eve of battle. You Jonah know how important such ritual is to disguise bitter self-knowledge or to bring it to light when our enemies - whom we would eat - bite into our own flesh. And now that we are on the eve of the holocaust, bitter and bitten alike, priest and victim alike, time has become invaluable." (Harris, Jonestown 16)

Throughout Jonestown Harris stresses the importance of transcending the binaries of self and other, recognizing the partial, composite and shared nature of being. Where Jones fails to bring seeming oppositions into relation - offering a "brand of religion [ ... ] split between the dead past (so-called) and the future (so-called), Jones's irredeemable universe, can prove a killing dogma, a killing manifesto directed at the heart of originality" (112) - Bone, despite his founding role in the cult, embraces the transformative capacity of his trauma; the potentiality that from the violence of war and terror, a creative impulse and original future may be borne.

Such, Deleuze argues in Nietzsche, is the very definition of the will-to-power. If, as noted above, a dialectical method problematically repeats the imperialist aim of the management of difference, here we find a further aspect of Deleuze's critique of Hegelianism: its fundamentally negative movement. What drives dialectical transformation is the pairing of opposed forces and, as such, Deleuze argues, "everything depends on the role of the negative" (Nietzsche 8). A body or state of affairs is thus defined as a reactive force: it is "an exhausted force which does not have the strength to affirm its difference, a force which no longer acts but rather reacts to the forces which dominate it"; "the speculation of the pleb, $[\ldots]$ the way of thinking of the slave" (9). Importantly, Hegel's master-slave relationship is revised by Nietzsche who argues that both slave and master may be characterized as dominated 
by reactive forces since each is defined by their relation to the other. Active and reactive forces are distinguished from one another, then, by the characteristic of their relation to other forces: the active force that simply is in itself (differing, in the first instance, with what it is) and which will appropriate the forces with which it comes into contact in a process of transformation and self-enrichment; and the forces that are defined through a reactive moment of external recognition (that differ, first, from all that it is not). ${ }^{2}$ The will-to-dominate, therefore, is the will to have one's power recognized: a reactive state characterized as an expression of ressentiment or bad conscience. Harris's Jonah Jones displays an “imperial hubris” (Harris, Jonestown 50) and "perverse longing for glory" (52); his desire to create a multi-ethnic utopia turns into an absolutism in which he sees himself pitted against law and state. Thus, Harris exposes Jones's reactive will-to-dominate. Yet, by contrast, Bone transgresses the binaries of victim and victor, self and other. The "structuralization of feud" (Harris, Explorations 132; emphasis original), or reactive framework (by which each side is determined by a negative opposition to the external other) is rejected by a character who embraces the power of transformation, creation and difference-in-itself: an active force that does not depend on external recognition or dialectical negation in order to simply be. In other words, between Jones and Bone, we move from the Nietzschean will-to-dominate to the will-to-power. ${ }^{3}$

The distinction between active and reactive forces, the will-to-power and the will-to-dominate, reflects Harris's sense of an immanent rather than transcendent ontology insofar as Nietzschean philosophy shows us that "it is important to see that forces enter into relations with other forces. Life struggles with another kind of life" (Deleuze Nietzsche 8; emphasis original). In other words, this model does not imply a transcendent or a priori absolute, but simply posits a relational whole in which life 
relates to another life of the same nature. The distinction to be drawn here depends upon the character of the relation: active or reactive. The impulse to destroy or dominate another force is a sign of ressentiment, a reactive power:

I felt it was useless running from the Predator any longer. My desire had been to destroy him by hook or by crook. So much so that unconsciously, subconsciously, I was driven to contemplate poisoning the air everywhere that he breathed, the seas and oceans and lakes and rivers in which he swam, the environments and places that clothed him. "Kill him even if it means killing yourself," Carnival Lord Death had said to me. [ ... ]

But the huntsman in the footfall of the Predator - close on the heels of the Predator - possessed a different tune.

"Leap," he said [ ... ] "into my net and help me to hold the heart of the Predator at bay within rhythms of profoundest self-confessional, selfjudgemental creativity." (Harris, Jonestown 75)

Here the desire to destroy the Predator is self-defeating: to poison the air that one breathes out of spite repeats the destructive will of the Predator and leads only to death. The huntsman, like the Nietzschean Übermensch, does not claim the will-todominate but the power of creativity associated with the will-to-power. He neither judges nor condemns the other, but draws from the relation a capacity for selfjudgement, self-evaluation: "Critique is not a re-action of re-sentiment but the active expression of an active mode of existence; attack and not revenge" (Deleuze, Nietzsche 3). The active force evaluates those other forces with which it comes into contact, "sensing whether they agree or disagree with us, that is, whether they bring 
forces to us" (Deleuze, Essays 135). In turn, what Harris terms "self-judgement" represents a creative and active process of self-evaluation and enrichment in relation to the forces that one encounters.

Deleuze expands upon this distinction between attack and revenge in his concepts of combat-between and combat-against:

combat-against tries to destroy or repel a force $[\ldots]$, but the combatbetween, by contrast, tries to take hold of a force in order to make it one's own. The combat-between is the process through which a force enriches itself by seizing hold of other forces and joining itself to them in a new ensemble: a becoming. (Essays 132)

This echoes precisely the Nietzschean distinction between active and reactive forces: combat-against operates through the will-to-dominate; combat-between is an active process which expresses the power of transformation and creation, "seizing hold of other forces" and creating "a new ensemble". In resisting the temptation to destroy the Predator, Bones, unlike Jones, follows "a different tune", "take[s] hold of a force in order to make it [his] own" and resists falling into ressentiment through the transformative will-to-power.

Harris's implicit understanding of the distinct processes of combat-against and combat-between enables him to redress seeming absolutes as partial forces that encounter other forces in a creative self-evaluation. His rereading of the myth of Orpheus and Eurydice, for example, demonstrates how profoundly this model challenges commonly held convictions: 
Let us recall that, in an ancient epic, Eurydice - the wife of the music-player Orpheus - is plucked away from him by Death, the Lord of the Under World. Orpheus is given a chance, it seems, to recover Eurydice but disobeys a command not to look back [ ... ]. Orpheus disobeys a command. Intuitively, subconsciously [ ... ] he glimmeringly perceived, when he looked back, that Eurydice would remain a pawn of the Under World if her apparent release had been sanctioned or sealed by Lord Death himself or itself. Something more radical and disturbing within death-dealing and conquistadorial regimes was gestating within layers of the unconscious. (Harris, Essays 190; emphasis original)

Orpheus disobeys the command of Lord Death; he refuses to become a "slave" (in the Nietzschean sense) to the underworld. In the same vein, Harris recognizes that if Eurydice escaped under terms dictated by Death then, although she may leave the underworld, she remains captive to Death's will. Such is the paradox of combatagainst that, in a different context, Wole Soyinka recognized when he argued that negritude would never offer a means to escape an imperialist mindset as long as it continued to seek the defeat of the other. ${ }^{4}$ In his struggle against Death, Orpheus can neither accept the terms dictated by the other nor repeat the imperialist aim of Death by seeking his destruction: "uncommon sense surely tells us that to stress conquest is to succumb to the very monster we fear" (Harris, Essays 191; emphasis original). Harris demands a "more radical" move than that. The myth must remain open to the potential to be re-read anew, appropriated in a transformative genesis of the imagination to uncover "new dimensions" (191). 
The distinction between the reactive will-to-dominate and creative will-topower also feeds into Harris's comments on the capacity for self-judgement in Jonestown. In his conversation with Mr Mageye, Bone muses on the concepts of justice and freedom: "Kingship witnesses to the agonizing problematic of freedom, the gift of freedom to ourselves within ourselves and yet bestowed upon us by some incalculable design in heaven and upon earth" (Jonestown 54). The king or God "is held as a guarantee" (54): the transcendent or a priori source of freedom and justice, the highest judge to which we may appeal. In the example of Orpheus and Eurydice, discussed above, Lord Death remains the guarantor of Eurydice's "freedom", but as such she remains trapped within Death's regime, determined by his terms. Once again this touches upon the distinction that Deleuze draws between active and reactive forces. "Men", writes Deleuze, "judge insofar as they value their own lots, and are judged insofar as a form either confirms or dismisses their claim" (Deleuze, Essays 129); or, for Harris:

To be just $[\ldots]$ was to serve one's vested interest absolutely, whether pleasure or profit, to sublimate or suppress or eclipse one's wounds in favour of strengthening a wall between oneself and the inferno that rules elsewhere [ $\ldots]$.

Injustice, on the other hand, bore on a coming abreast of wounds one has suffered in the past through which one knows the pain in oneself and others, pain of mind that revives the Soul of Compassion beyond all machineries of the law of Death or of the state of embalmed institutions. (Harris, Jonestown 72) 
To judge or seek justice presupposes an act of evaluation dependent on a transcendent or a priori ideal against which an act or thing may be measured: a critique conceived of as a reaction to external or higher guarantee.

Judgement is presented as the antithesis to the transformational life of Bone. Instead, Harris links the regenerative vision of his novel to the ability to transform one's wounds. As Said suggests, the promise of postcolonial literatures resides in this "coming abreast of wounds one has suffered", the resignifying of the colonial past in the "scars of humiliating wounds, as instigation for different practices, as potentially revised visions of the past tending towards a new future" (Said 34-35). Of course, from the outset of Jonestown, this is precisely the project of Bone's Dream-Book in which he relates the tragedy: "I needed to revisit the scene and the entire environment [... ], by retracing my steps, by accepting my wounds and lameness and the speed of light with which one travels back into the past from bleak futures" (170; emphasis added). To deny, "sublimate or eclipse" one's wounds is to succumb to ressentiment; to accept one's wounds, "embracing the event and the transformations it induces - not its brute actuality" (Reynolds 153), is amor fati and a will-to-power.

To understand why the events that wound us retain a transformative capacity returns us to the beginning of this essay where I outlined Deleuze's concept of different/ciation as the becoming-actual of the virtual and creation of the new. The virtual-actual pairing is key to Deleuze's ontology. However, to his philosophy of time he adds another, parallel, dualism: Aion and Chronos: "Chronos is the present which alone exists. It makes of the past and future its two oriented directions, so that one goes always from the past to the future [ ... ] Aion is the past-future" (Deleuze, Logic 89). Chronos is linear, sequential time and belongs to the realm of the actual; Aion is a pure, virtual plane. Thus, recalling the process of different/ciation, for 
Deleuze any event occurs both within "actual", linear time and persists as a pure or virtual form: "What History grasps of the event is its effectuation in states of affairs or in lived experience, but the event in its becoming, in its specific consistency, in its self-positing as a concept, escapes History" (Deleuze and Guattari 110). In other words, what history recalls of the event is its "brute actuality" in linear time. By the same token, the counter-actualization of the event returns us to its "specific consistency" on the virtual plane of composition: the pure difference that escapes history.

The revisionary impulse of Bone's Dream-Book, therefore, has philosophical resonance exceeding what Louis Simon characterizes as a "move beyond the horror and incomprehensibility of the journalistic record of the Jonestown massacre" (211). Simon is right to identify this process as a revisionary engagement both with the recorded past and with memory, however, to simplistically label the latter as a "nonWestern conception" (213) ignores the important parallels Harris's work holds with that of philosophers such as Deleuze and Henri Bergson, who explore the creative potential of a virtual or pure concept of the past. Furthermore, Deleuze's account reminds us that it is never simply a question of revisiting the memory of an individual, but the return to or counter-actualization of a shared plane of immanence. As Bone claims in his opening "letter to WH", "I drifted into what seemed an abnormal lucidity upon chasms of time [ ... ]. One becomes, it seems, a vessel of composite epic, imbued with many voices, one is a multitude" (5). What Harris refers to as Memory Theatre, then, evokes a shared but only partially grasped past that may be rehearsed anew. At the same time, by reading this through a Deleuzian lens specifically through his pairing of Aion and Chronos as the two, irreducible but coexistent temporalities - one gains a sense both of the virtual potential of the past to 
become-new and a common-sense linear sequence of time. To argue, as Paula Burnett has, that Harris wholly rejects teleology and a diachronic conception of time, unfixing "the locatedness of the past, such as 1978 in Jonestown", freeing it "from its fixedness so that it can signify afresh in the now or the future" (Burnett 221), glosses over the specificity of Jonestown. Historical markers, such as the date of the Jonestown massacre, 18 November 1978, or the night that Bone's mother was murdered, 24 March 1939 (cf. 35), are very precisely located in the text. In other words, while the revisionary potential for Memory Theatre lies in the counter-actualization of events in linear, historical time - returning to a pure, virtual temporality - this should not be mistaken as the outright rejection of any possibility of a linear concept of time. To avoid the chaotic, formless plane of immanence that Whitehead cautions against while retaining the revisionary potential of the Deleuzian virtual, both Aion and Chronos are necessary actors in postcolonial Memory Theatre.

Furthermore, in Bignall's characterization of postcolonial critique as both "the disruption and 'counter-actualisation' of the problematic post-colonial present $[\ldots]$, and the subsequent reconstruction of an alternative postcolonial present" (114; emphasis original), it is precisely by means of the Aion-Chronos pairing that she constructs her method. In order to create an alternative present, one first counteractualizes the wounding event, returning to the virtual plane of composition, and then re-actualizes a new present/future (according to the logic of different/ciation as the eternal return of difference). By reliving the Jonestown tragedy, Bone counteractualizes the trauma that wounds him. But far from falling into ressentiment, he lives creatively out of the wounding event by imagining an alternative present-future: "Continuities running out of the mystery of the past into the unknown future yield proportions of originality, proportions of the 'genuinely new'" (Jonestown 6). 
Creation, the ability to counter-actualize the events that wound us and construct an alternative future freed from the oppositional or imperialist ideologies that limit us, as Harris and Said implicitly recognize, marks the active force, will-to-power and combat-between of a properly postcolonial consciousness.

Harris's own philosophy of time, then, incorporates the two coexistent temporalities of Aion and Chronos while celebrating the creative force of different/ciation as the potential of a postcolonial present/future freed from "imperial hubris" (50). Indeed, Jonestown has inspired a number of different interpretations of Harris's philosophy of time - for example, the work of Paula Burnett, Carmen Concilio, Louis Simon and Stephanos Stephanides. The latter joins critics such as Andrew Benjamin, C. L. R. James and Gregory Shaw who explore the links between Harris's work and various continental philsophers. ${ }^{5}$ In Stephanides's reading of Jonestown, a number of the concepts discussed in this essay - becoming, the rejection of final unity, and the theorization of two temporalities - are explored in relation to the philosophy of Walter Benjamin, most notably his theory of language and messianic concept of time. Significantly, while deconstruction emphasizes the différance of translation, in Benjamin's hands the question of translatability is specifically linked to his philosophical account of history. For Benjamin, Stephanides argues:

The possibility of pure language ensues from the language being always already displaced from a utopian original unity or wholeness, and this possibility may be fulfilled in "God's remembrance" [ ... ]. The gesture to salvage comes after the Fall $[\ldots]$. The fall of language and the impulse to 
salvage is not simply a nostalgia for origins but an attempt that "we might salvage a future from the ruins of the past". (235)

Here the familiar trait of regeneration in the face of trauma and disaster, so apparent from the outset of Jonestown, is given additional resonance as Stephanides links it to Benjamin's famous account of the angel of history. Yet while Benjamin's philosophy of history does depart from a strictly Hegelian sense of dialectical process, stresses becoming over stasis - offering an "always deferred" teleology (Stephanides 236) and moves "from mimesis or equivalence to difference in translation" (236), when viewed from a Deleuzian perspective, one uncovers the limitations of Benjamin's philosophy of history for a properly postcolonial vision of the past.

Contrasting Benjaminian and Deleuzian philosophies, Laura Penny argues that although "Benjamin and Deleuze and Guattari all underline the link between creativity and futurity, or becoming [ ... ] they ultimately conceive of this immanence differently" (n. pag.). And it is precisely the difference between these two positions, and, more specifically, how these different philosophers address the concept of judgement, that is, I argue, crucial when evaluating their significance for Harris. As Penny argues:

The most significant difference between these two thinkers is that Benjamin maintains an admittedly idiosyncratic theological framework that Deleuze explicitly criticises and rejects. Benjamin's theologically-inflected theory of language, and his messianic notion of history for the dead, act as supplements to criticism, insofar as they take up the work of judgement, and 
refer it to a higher power, to the distant and improbable union that reconciles and redeems all. (n. pag.)

In other words, the Benjaminian reading of language, messianic time and critique ultimately depends on a transcendent, higher power as guarantee; a deferred and displaced, but nevertheless assumed, absolute source of judgement and justice.

As signalled above, Deleuze wrests judgement and critique away from a priori or transcendent foundations precisely because they forestall the potential for creation, originality and newness. As Deleuze argues:

judgement $[\ldots]$ presupposes preexisting criteria (higher values), criteria that preexist for all time (to the infinity of time), so that it can neither apprehend what is new in an existing being, nor even sense the creation of a mode of existence [ ... ]. Judgement prevents the emergence of any new mode of existence. For the latter creates itself through its own forces, that is, through the forces it is able to harness, and is valid in and of itself inasmuch as it brings the new combination into existence. (Deleuze, Essays 134-35)

To judge is to depend on the knowledge that an external or transcendent measure exists against which something may be judged: a (Platonic) transcendence at the heart of immanence and sign of a reactive will-to-dominate. Furthermore, since judgement depends on "preexisting criteria $[\ldots]$ that preexist for all time" it cannot offer a basis for the production of genuine originality. It fails precisely on the same grounds as the Hegelian dialectic: 'reality is not 'created' but 'realised' in this process, in the sense that everything that comes to be always already exists, or is pre-given, and is simply 
'made real'” (Bignall 34). Genuine newness or creation cannot be judged from predetermined standards or norms; it does not react but rather creates its own lines of (immanent) becoming: "It is not a question of judging other existing beings, but of sensing whether they agree or disagree with us, that is whether they bring forces to us" (Deleuze, Essays 135). Living creatively out of the wounding event, evaluating forces and how they might enrich us, this is the will-to-power and the expression of an active mode of existence free from ressentiment.

As Jonestown moves towards its conclusion, Bone comes face to face with his own judges. He finds himself mistaken for Deacon by the judges who refuse to recognize the partial existence or cross-cultural masks that Bone wears: "Deacon's judges which would then become my judges in the altered textuality of the Play" (Harris, Jonestown 224; emphasis original). Determined to hold Deacon to account for stealing the fortune of Roraima, the judges pass sentence on Bone:

I was a mere Colonial. Not an Imperialist [ ... ]. Are Colonials the only potential creators of the genius of Memory theatre? I was weak, but I had gained the other side of the Dream.

"Who then are we to judge?"

"Judge me," I said at last. "I am here before you. I have nothing. I am poor. Judge me. It is no accident."

They took me without further ado to the edge of the cliff $[. .$.$] . It fell with$ me, the Predator fell with me, when their hands, the judges' hands, drove me over the edge of the cliff $[\ldots]$. The Predator peered through me, in me, but was held at bay in the net. We stood face to face, Dread and I, Predator and I. Old age and youth parted and I was naked in the lighted Darkness of the Self 
[ ... ]. Lightness becomes a new burden upon the extremities of galaxies in which humanity sees itself attuned to the sources and origins of every memorial star that takes it closer and closer - however far removed - to the unfathomable body of the Creator. (233-44)

As in Harris's rereading of Orpheus and Eurydice, Bone's redemption cannot be conceived within the framework of judgement and punishment. Sentenced to death, Bone does not escape his fate by, like Eurydice, fleeing death. Salvation and repentance, rather, "take us beyond the framed and flat world into the Virginarchetype and the rhetoric of intercourse with reality shorn of violence" (227). The judges who pass sentence seek reparation and justice for the crime committed against them by Deacon: an attempt to "sublimate or suppress or eclipse" their wounds (72) by recourse to a measure of judgement dependent on absolute values such as life and death, law and anarchy, self and other. To this Harris contrasts "injustice", "a coming abreast of wounds one has suffered in the past through which one knows the pain in oneself and others" and "the Soul of Compassion beyond all machineries of the law of Death or of the state of embalmed institutions" (72).

In this closing paragraph, Bone moves "beyond" all frames and evokes something of the vitalistic force ("the unfathomable body of the Creator") that may be traced back to Harris's earliest novels. What is key to unravelling the Dream-book of Bone's trauma is the contrast that Harris establishes between active and reactive forces. To judge, to rule with the absolutism of Jones, to seek to erase or sublimate the past: these acts fall on the side of the will-to-dominate. The redemptive vision that Bone seeks on the other hand is realized through an active engagement with the forces that he encounters: living creatively out of the wounding event. More crucially, by 
means of a dialogue with the philosophy of Deleuze, this active mode of existence may not only be linked to the concepts of judgement, immanence and counteractualization (key, as Bignall argues, to postcolonial critique), but can be seen to feed into a philosophy of time that maintains both our experience of linear Chronos and sense of the radical potentiality of the future to become new in Aion. Harris, like Deleuze, may stress the importance of the latter, but both are essential components in his postcolonial philosophy of time.

\section{Notes}

1. For a detailed commentary on this shift see Mullarkey.

2. This paraphrases Deleuze: "in Bergson [...] the thing differs with itself first, immediately. According to Hegel, the thing differs with itself because it differs first with all that it is not" (in Hardt 7; emphasis original).

3. For commentary on the importance of this distinction for postcolonial thought, see Burns (113-6).

4. Soyinka's argument that negritude trapped "itself in what was primarily a defensive role" (129) and "stayed within a pre-set system of Eurocentric intellectual analysis" (136), highlights this point: counter-colonial discourse is trapped within a "pre-set system" in which the black man is cast as other.

5. James discusses Harris in light of Heidegger (157-72); Shaw cites Hegel as a more significant influence (141-51). Andrew Benjamin draws on Nietzsche to explore the relevance of repetition rather than dialectical negation in The Eye of the Scarecrow.

\section{Note on contributor}


Lorna Burns is Lecturer in Postcolonial Literatures in the School of English at the

University of St Andrews. She is the author of Contemporary Caribbean Writing and

Deleuze: Literature Between Postcolonialism and Post-Continental Philosophy

(Continuum 2012) and co-editor of Postcolonial Literatures and Deleuze: Colonial

Pasts, Differential Futures (Palgrave 2012).

\section{References}

Benjamin, Andrew. "The Crumbling Narrative: Time, Memory and the Overcoming of Nihilism in The Eye of the Scarecrow". The Literate Imagination. Ed. Michael Gilkes. London: Macmillan, 1989. 82-92.

Bignall, Simone. Postcolonial Agency: Constructivism and Critique. Edinburgh: Edinburgh UP, 2010.

Burnett, Paula. "Memory Theatre and the Maya: Othering Eschatology in Wilson Harris's Jonestown". Journal of Caribbean Literatures. 2. 1-3 (2000): 215-232. Burns, Lorna. Contemporary Caribbean Writing and Deleuze: Literature Between Postcolonialism and Post-Continental Philosophy. London: Continuum, 2012.

Colebrook, Claire. Gilles Deleuze. London: Routledge, 2002.

Concilio, Carmen. “Cryptic Chaosmos in Wilson Harris's Jonestown”. Journal of Caribbean Literatures. 2. 1-3 (2000): 242-252.

Deleuze, Gilles. Difference and Repetition. Trans. Paul Patton, London: Continuum 2004.

---. Essays Critical and Clinical. Trans. Daniel Smith and Michael Greco.

Minneapolis: U of Minnesota P, 1997.

---. The Logic of Sense. Ed. Constantin V. Boundas. Trans. Mark Lester with Charles Stivale. New York: Columbia UP, 2004. 
---. Nietzsche and Philosophy. Trans. Hugh Tomlinson. London: Continuum, 2006.

Deleuze, Gilles and Félix Guattari. What Is Philosophy? Trans. Graham Burchell and Hugh Tomlinson. London: Verso, 1994.

Emery, Mary Lou. “The Politics and Performance of Ecstasy in Wilson Harris's Writing”. Journal of Caribbean Literatures. 2. 1-3 (2000): 66-81.

James, C. L. R. Spheres of Existence. London: Allison and Busby ltd, 1980.

Hardt, Michael. Gilles Deleuze: An Apprenticeship in Philosophy. London: UCLP, 1993.

Harris, Wilson. Explorations. Ed. Hena Maes-Jelinek. Sydney: Dangaroo Press, 1981. ---. Jonestown. London: Faber and Faber, 1996.

---. Selected Essays. Ed. Andrew Bundy. London: Routledge, 1999.

Maes-Jelinek, Hena. “Another Future for Post-Colonial Studies? Wilson Harris’ PostColonial Philosophy and the 'Savage Mind"'. Wasafiri. 12. 24 (1996): 3-8.

Milton, John. Paradise Lost. Oxford: Oxford UP, 2005.

Mullarkey, John. Post-Continental Philosophy. London: Continuum, 2006.

Penny, Laura "Parables and Politics: How Benjamin and Deleuze and Guattari Read Kafka”. Theory and Event. 12.3 (2009): Project MUSE. Web. 11 Dec. 2012. $<$ http://muse.jhu.edu/>

Reynolds, Jack. "Wounds and Scars: Deleuze on the Time and Ethics of the Event". Deleuze Studies. 2.1 (2007): 144-66.

Said, Edward. Culture and Imperialism. London: Chatto and Windus, 1993.

Shaw, Gregory. "The Novelist as Shaman: Art and Dialectic in the Work of Wilson Harris”. The Literate Imagination. Ed. Michael Gilkes. London: Macmillan, 1989. $141-51$. 
Simon, Louis. "Writing, Reading and Altered Consciousness in Jonestown". Journal of Caribbean Literatures. 2. 1-3 (2000): 207-214.

Soyinka, Wole. Myth, Literature and the African World. Cambridge: Cambridge UP, 1976.

Stephanides, Stephanos. “Goddesses, Ghosts and Translatability in Wilson Harris's Jonestown". Journal of Caribbean Literatures. 2. 1-3 (2000): 233-241.

Williams, James. "Immanence and Transcendence as Inseparable Processes: On the Relevance of Arguments from Whitehead to Deleuze Interpretation”. Deleuze Studies. 4 (2010): 94-106. 